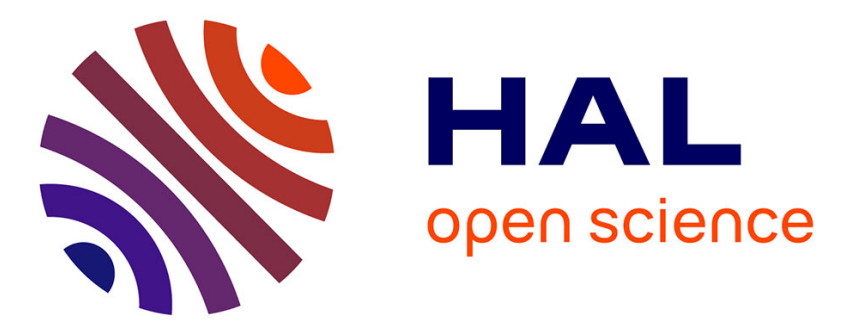

\title{
Kinematics, topography, shortening, and extrusion in the India-Eurasia collision
}

\author{
Xavier Le Pichon, Marc Fournier, Laurent Jolivet
}

\section{To cite this version:}

Xavier Le Pichon, Marc Fournier, Laurent Jolivet. Kinematics, topography, shortening, and extrusion in the India-Eurasia collision. Tectonics, 1992, 11 (6), pp.1085-1098. 10.1029/92TC01566 . insu00726608

\section{HAL Id: insu-00726608 https://hal-insu.archives-ouvertes.fr/insu-00726608}

Submitted on 30 Aug 2012

HAL is a multi-disciplinary open access archive for the deposit and dissemination of scientific research documents, whether they are published or not. The documents may come from teaching and research institutions in France or abroad, or from public or private research centers.
L'archive ouverte pluridisciplinaire HAL, est destinée au dépôt et à la diffusion de documents scientifiques de niveau recherche, publiés ou non, émanant des établissements d'enseignement et de recherche français ou étrangers, des laboratoires publics ou privés. 
TECTONICS, VOL. 11, NO. 6, PAGES 1085-1098, DECEMBER 1992

KINEMATICS, TOPOGRAPHY, SHORTENING, AND EXTRUSION IN THE INDIA-EURASIA COLLISION

\author{
Xavier Le Pichon, Marc Fournier, and Laurent \\ Jolivet \\ Laboratoire de Géologie, Département Terre- \\ Atmosphère-Océan, Ecole Normale Supérieure, \\ Paris, France
}

\begin{abstract}
We examine the problem of partitioning between shortening and extrusion in the India-Asia collision since $45 \mathrm{Ma}$. We compute the amount of shortening expected from the kinematics of India's motion with respect to Eurasia, using the reconstruction at collision time to put bounds on the possible amounts of surface loss within Greater India and within Eurasia. We then compute the amounts of surface loss corresponding to the thickened crust of Tibet and of the Himalayas, assuming conservation of continental crust. The spatial distribution of the topography reveals a large systematic deficit of crustal thickening distributed rather uniformly west of the eastern syntaxis but an excess of shortening east of it. This distribution indicates an important eastward crustal mass transfer. However, the excess mass east of the eastem syntaxis does not account for more than one third to one half of the deficit west of the eastern syntaxis. The deficit may be accounted either by loss of lower crust into the mantle, for example through massive eclogitization, or by lateral extrusion of nonthickened crust. A mass budget of the crust of the Himalayas indicates that lower crust has not been conserved there, but the deficit is so large that local loss in the mantle is unlikely to be the unique cause of the deficit. Alternatively, following Zhao and Morgan [1985], lower crust may have been transferred below the Tibetan crust. We conclude that a combination of possible transfer of lower crust to the mantle by eclogitization and lateral extrusion has to account for a minimum of one third and a maximum of one half of the total amount of shortening between India and Asia since $45 \mathrm{Ma}$. This conclusion leaves open the possibility that the partitioning between extrusion and loss of lower crust into the mantle on the one hand and shortening on the other hand has significantly changed during the $45 \mathrm{~m}$.y. history of the collision.
\end{abstract}

\section{INTRODUCTION}

The indentation of India has resulted in deformation distributed over a vast area of the Asian continent. A major unresolved problem concerns the quantitative partitioning of the deformation between shortening (through thickening) and extrusion [e.g., Tapponnier et al., 1986; Dewey et al., 1989]. In this

Copyright 1992 by the American Geophysical Union.

Paper number $92 \mathrm{TC} 01566$.

0278-7407/92/92TC-01566\$10.00 paper, we compute the amount of surface shortening expected from the kinematics of India with respect to Asia since collision and use the reconstruction at collision time to put bounds on the amounts of shortening within Greater India and within Asia. We compare these estimates to the amount of surface shortening implied by the topography of Asia around India, in order to determine the relative amounts of shortening and extrusion and to discuss their spatial distribution.

\section{SHORTENING BETWEEN INDIA AND EURASIA FROM PLATE KINEMATICS}

Patriat and Achache [1984] derived fairly precise relative motions of India with respect to Eurasia using the detailed Indian Ocean magnetic data published by Patriat [1983]. Since this paper, several reconstructions of the motion of India with respect to Eurasia have been published [e.g., Besse and Courtillot, 1988; Dewey et al., 1989]. Although all solutions indicate a dramatic slowdown of the northward relative motion of India and some reorientations of the motion from anomalies 24 to 30 , significant differences still exist because the reconstructions require summing the motions of three ridge plate boundaries with relatively large uncertainties. However, the amounts of shortening obtained with these different solutions are not significantly different for our purpose. We will demonstrate this by comparing the solution we use with the solution published by Dewey et al. [1989].

We have chosen the kinematic parameters of Besse and Courtillot [1988] for anomalies 6 and 21. Anomaly 6 is given as $23 \mathrm{Ma}$ in the Harland et al. [1982] scale they adopt. We choose instead to adopt the more recent scale of Kent and Gradstein [1986] which gives an age of $20.5 \mathrm{Ma}$. Similarly, for anomaly 21 , we use an age of $49 \mathrm{Ma}$ instead of 48.5 .

We adopt the pole given by De Mets et al. [1990] for the present motion of India with respect to Asia (see Table 1). This pole takes into account shortening between India and Australia along the eastern equatorial Indian Ocean. We assume that this shortening started $7 \mathrm{~m}$.y. ago as indicated by the dating of a widespread unconformity marking the onset of deformation [Leg 116 Shipboard Scientific Party, 1987]. Royer and Chang's [1991] kinematic study suggests that the deformation may have started earlier, between anomalies 5 (10.5 Ma) and 6 (20.5 $\mathrm{Ma}$ ), but the available geologic evidence does not confirm this hypothesis.

Discussions of the amount of shortening absorbed within the India-Eurasia collision are generally made in terms of linear motion. However, the shortening is obviously at least partly redistributed in a rather complex way, and we consequently need areal estimates of shortening [Zhao and Morgan, 1985]. The rate of surface shortening along a portion of boundary $\mathrm{AB}$ is

$$
\dot{S}_{A B}=\int_{A}^{B}-\vec{v} \cdot \hat{n} d s
$$


TABLE 1. India-Eurasia Relative Rotations

\begin{tabular}{ccccc}
\hline & \multicolumn{2}{c}{ Rotation Pole } & & \\
\cline { 2 - 3 } Age, Ma & North & East & Angle & Reference \\
\hline $0-7$ & $24.4^{\circ}$ & $17.7^{\circ}$ & $3.7^{\circ}$ & 1 \\
$7-20.5$ & $16.7^{\circ}$ & $38.9^{\circ}$ & $10.0^{\circ}$ & 2 \\
$20.5-49$ & $14.4^{\circ}$ & $35.0^{\circ}$ & $19.7^{\circ}$ & 3 \\
\hline
\end{tabular}

References are 1, De Mets et al. [1990]; 2, anomaly 6 [Besse and Courtillot, 1988]; and 3, anomaly 21 [Besse and Courtillot, 1988].

where $\vec{v}$ is the relative velocity across this boundary and $\hat{n}$ is the unit vector normal to the boundary. But

$\vec{v} \cdot \hat{n} d s=\omega R^{2} \cos \varphi d \varphi$

where $\varphi$ is the Eulerian latitude, $R$ the radius of the Earth, and $\omega$ the rate of rotation. Thus

$\dot{S}_{\mathrm{AB}}=\omega \mathrm{R}^{2}\left(\sin \varphi_{\mathrm{B}}-\sin \varphi_{\mathrm{A}}\right)$

and only depends on the Eulerian latitude of the two extremities of boundary considered. For a finite length of time $t$,

$\Delta \mathrm{S}_{\mathrm{AB}}=\dot{\mathrm{S}}_{\mathrm{AB} \cdot \mathrm{t}}$

Thus $\Delta S_{\mathrm{AB}}$ is independent of the actual shape of the portion of boundary between points $A$ and $B$.

We compute the amount of shortening between the western (point A) and eastern (point B) syntaxes (Figure 1). Point C, close to Karachi $\left(25^{\circ} \mathrm{N}, 66^{\circ} \mathrm{E}\right)$, and $\mathrm{D}$, close to Rangoon $\left(16^{\circ} \mathrm{N}, 97^{\circ} \mathrm{E}\right)$, mark the southern limits of the western and eastern limbs (Figure 1). The eastern limb is transform and there is no significant shortening across it, whereas some shortening, which we compute, occurs along the western limb (between point $C$ and point $A$ ). Table 1 gives the parameters of reconstruction. Tables 2,3 , and 4 give the main results of the computations. Figure 1 shows the path of India relative to Eurasia in its present position.

\section{Collision Time}

As mentioned earlier, all kinematic solutions reveal a major slowdown and some reorientation of the relative motion between anomalies $24(56 \mathrm{Ma})$ and 20 (46 Ma). Besse and Courtillot [1988] showed that paleomagnetic data also indicate a rather sharp slowdown of the meridional component of convergence between India and Eurasia sometime between 55 and $40 \mathrm{Ma}$.

Although the kinematic uncertainties are still too large to choose unambiguously a collision time within this 55-40 Ma window, one can get some indirect estimates of the collision time from the now well-understood kinematics of the Central Indian
Ocean Ridge which was situated directly south of India and presumably was most affected by any change in the "absolute" motion of India. Patriat [1983] had shown that this ridge was affected by a major reorganization between anomalies 20 and 18 (46 and $43 \mathrm{Ma}$ ) and that a sharp slowdown of the opening rate from 16 to $10 \mathrm{~cm} \mathrm{yr}^{-1}$ occurred earlier, between anomalies 22 and 21 (51 and $49 \mathrm{Ma}$ ). The less detailed but more constrained analysis of Royer and Sandwell [1991] confirms these results. The spreading velocity is very stable at $5-6 \mathrm{~cm} \mathrm{yr}^{-1}$ after anomaly $18(43 \mathrm{Ma})$. The only significant reorganization of spreading occurs between anomalies 20 and 18 (46 and $43 \mathrm{Ma}$ ). Thus the conclusion of Dewey et al. [1989] that the main collision occurred near $45 \mathrm{Ma}$ seems quite reasonable from a kinematic point of view and we adopt it.

Geologic evidence indicates that the northern Tethys margin was an Andean type margin with active shortening in Upper Cretaceous time. Volcanic activity continued into lower Eocene [Mercier et al., 1987; Searle et al., 1987]. Ophiolites were obducted onto this margin in Upper Cretaceous time (the Xigaze ophiolites) in the main part of the range [Mercier et al., 1987]. Farther to the west, ophiolites were obducted on the southern margin sometime in early Paleocene [Searle et al., 1987] at a time when India was situated very far from Asia. According to Mercier et al. [1987, p. 277) "the first deformations which clearly demonstrate that an India-Asia collision occurred took place subsequent to early Eocene time". This is the time at which neritic limestones, present both on the northern and southern margins, are deformed and the whole belt emerges. Conglomerates are then deposited in the Zang Po suture zone on top of a presumably trench melange [Searle et al., 1987]. Thus, although some evidence of tectonic activity, possibly due to collision with offshore arcs, exists on the Asian margin since Upper Cretaceous time, the geologic evidence suggests that true continental collision occurred in middle Eocene time, near $45 \mathrm{Ma}$, and was active along the whole boundary at the latest by the end of Eocene (37 Ma).

Treloar and Coward [1991] argue that the collision occurred first in the western syntaxis, near 55-50 Ma and then at about $45 \mathrm{Ma}$ in the main part of the range. There is little geologic evidence indicating significant differences in timing of orogeny between these two 
zones (see the compilation of Searle et al. [1987]) and the main argument in favor of this hypothesis comes from the present diamond shape of India and the fact that the eastern syntaxis was situated 1300

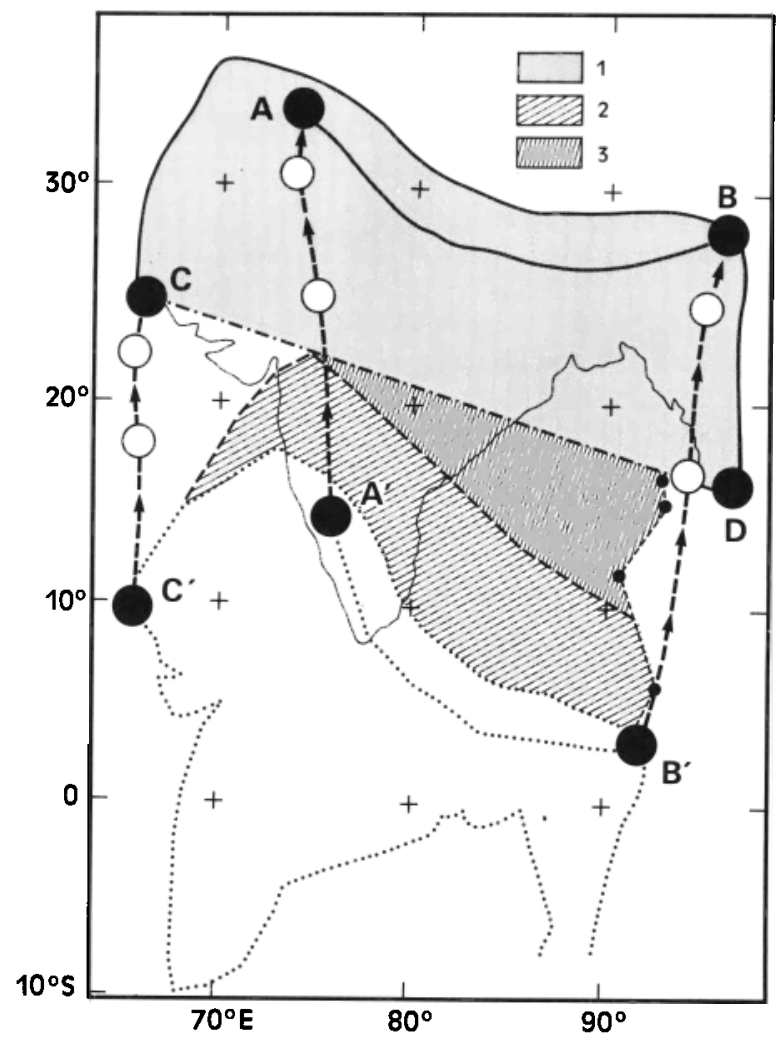

Fig. 1. Kinematics of India with respect to Eurasia since $45 \mathrm{Ma}$ according to the parameters of Table 1. The position of India is shown 45 m.y. ago ( $A^{\prime} B^{\prime} C^{\prime}$ ) and today $(\mathrm{ABCD})$ in Eurasian coordinates. $A$ and $\mathrm{B}$ correspond respectively to the western and eastern syntaxes of the Himalayas. C (near Karachi) and D (near Rangoon) define the approximate southern limits of the western and eastern branches of the transform-collision belts. Intermediate positions of $\mathrm{ABC}$ are shown at $20.5 \mathrm{Ma}$ (anomaly 6 ) and $7 \mathrm{Ma}$ by open circles. The outline of the Himalayas is taken along the Main Boundary Thrust to the south and the Indus Suture to the north. The eastward limit of northem Greater India at $45 \mathrm{Ma}$ is shown by a dashed line joining small solid circles [after Powell et al., 1988]. It defines the maximum extent of Greater India. The minimum extent is based on estimates of shortening in the Himalayas. The minimum extent of former Asia is obtained by joining $C$ to $D$. The maximum extent of former Asia would have extended southward to the minimum extent of Greater India. Note the probable presence of an oceanic gap northwest of $A^{\prime} C^{\prime}$. Patterns are 1 , surface lost by Asia; 2, minimal surface lost by Greater India; and 3, maximum surface lost by Greater India. $\mathrm{km}$ farther south than the western one at collision time. We will come back to this point later when discussing the former configurations of Greater India and Asia.

\section{Shortening Since $45 \mathrm{Ma}$}

Tables 2 to 4 summarize the main results of our kinematic analysis. The total distances traveled by the western syntaxis (point A) and eastern syntaxis (point B) since $45 \mathrm{Ma}$ are $2150 \mathrm{~km}$ and $2860 \mathrm{~km}$, respectively, corresponding to average velocities of 48 and $64 \mathrm{~mm} \mathrm{yr}^{-1}$. The velocities were very stable until $7 \mathrm{Ma}$ and then decreased somewhat (Table 2).

However, we are more interested in shortening distances perpendicular to the boundary. The distance components at $\mathrm{A}$ and $\mathrm{B}$, perpendicular to the great circle joining $A$ to $B$, are reduced to $1850 \mathrm{~km}$ and $2600 \mathrm{~km}$, respectively.

The shortening velocity is constant before $7 \mathrm{Ma}$ at $40 \mathrm{~mm} \mathrm{yr}^{-1}$ near A and $60 \mathrm{~mm} \mathrm{yr}^{-1}$ near B (Table 3). There is thus a $50 \%$ increase in shortening velocity over the $2180 \mathrm{~km} \mathrm{AB}$ distance. The obliquity of the motion with $\mathrm{AB}$ (the angle between the motion vector and the perpendicular to $\mathrm{AB}$ ) is about $30^{\circ}$ in the west and $20^{\circ}$ in the east. This means that the obliquity with the arcuate mountain belt was about $50^{\circ}-60^{\circ}$ in the west but fairly small in the east.

A $20^{\circ}$ clockwise rotation of the motion vectors occurred 7 m.y. ago [De Mets et al., 1990] with the formation of the equatorial Indian Ocean deformation zone. As a result, the obliquity between great circle $\mathrm{AB}$ and the motion vectors disappeared at this time (Table 2). Since $7 \mathrm{Ma}$, the Indian indentor has moved perpendicular to $A B$ and the significant dextral component of motion along $\mathrm{AB}$ which existed previously has disappeared. The shortening velocity slightly increased at point $A$ to $45 \mathrm{~mm} \mathrm{yr}^{-1}$ but decreased at point $B$ to $55 \mathrm{~mm} \mathrm{yr}^{-1}$. Consequently, there is now only a $20 \%$ difference in shortening velocity between $\mathrm{A}$ and $\mathrm{B}$ compared to $50 \%$ prior to $7 \mathrm{Ma}$.

The total amount of surface elimination across $\mathrm{AB}$ since $45 \mathrm{Ma}$ is $5 \times 10^{6} \mathrm{~km}^{2}$ (Table 4), about twice the present surface of Tibet as noted by Zhao and Morgan [1985]. Across the western limb, between A and $C$, the surface elimination since $45 \mathrm{Ma}$ is $1.8 \mathrm{x}$ $10^{6} \mathrm{~km}^{2}$. The rate of surface elimination across $A B$ since $45 \mathrm{Ma}$ has been quite constant at $1.1 \times 10^{5}$ $\mathrm{km}^{2} \mathrm{~m} . \mathrm{y}^{-1}$ corresponding to an average shortening velocity of $51 \mathrm{~mm} \mathrm{yr}^{-1}$. The rate of surface elimination across $\mathrm{AC}$ was $0.43 \times 10^{5} \mathrm{~km}^{2}$ m.y. prior to $7 \mathrm{Ma}$ and decreased to 0.28 after $7 \mathrm{Ma}$, corresponding to velocities of 36 and $23 \mathrm{~mm} \mathrm{yr}^{-1}$, respectively. This sharp decrease $7 \mathrm{~m} . \mathrm{y}$. ago is due to the $20^{\circ}$ rotation of the motion vectors at this time.

To conclude, the total amount of surface eliminated since $45 \mathrm{Ma}$, if collision was indeed complete at this time, is $6.8 \times 10^{6} \mathrm{~km}^{2}$. The rate of elimination was constant through $\mathrm{AB}$ although a $35^{\circ}$ to $25^{\circ}$ right lateral obliquity disappeared $7 \mathrm{~m}$.y.ago. 
The rate of elimination significantly decreased 7 m.y. ago through $\mathrm{BC}$ as the left lateral obliquity increased from about $35^{\circ}$ to $55^{\circ}$.

\section{Former Configuration of Greater India and of the Asian Southern Boundary}

To derive the figure of $6.8 \times 10^{6} \mathrm{~km}^{2}$ of surface elimination, we have assumed that the whole boundary $\mathrm{CAB}$ was in collision $45 \mathrm{~m}$.y. ago and that consequently there was no oceanic space left between India and Asia along this boundary. We mentioned earlier that Treloar and Coward [1991] have proposed that collision occurred a few millions years earlier near A than near $\mathbf{B}$. This hypothesis poses the question of the former shapes of the northern border of India and the southern border of Asia. It has been the subject of a large amount of debate summarized by Treloar and Coward [1991].

Figure 1 shows that India has penetrated within the Asian continent a distance of about $1250 \mathrm{~km}$. As noted by Tapponnier et al. [1986], it is unlikely that India exactly docked within a preexisting indentation in Asia. Let us assume that this "hole" is indeed the result of Asian shortening and that consequently the boundary of Asia was along great circle CD. This crude assumption probably gives a minimum estimate of the Asian shortening, that is, $3.45 \times 10^{6} \mathrm{~km}^{2}$ (note that in this paper we integrate exactly the surfaces enclosed by the boundaries as given in the figures). This shortening may have resulted from crustal shortening and (or) lateral expulsion.

TABLE 2. Distance Traveled by Point and Average Velocity

\begin{tabular}{ccccccccc}
\hline & \multicolumn{2}{c}{ A } & & \multicolumn{2}{c}{ B } & & \multicolumn{2}{c}{ C } \\
\cline { 2 - 3 } Age, Ma & Distance & Velocity & & Distance & Velocity & & Distance & Velocity \\
\hline $0-7$ & 314 & 45 & & 385 & 55 & & 284 & 41 \\
$7-20.5$ & 651 & 48 & & 898 & 67 & & 500 & 37 \\
$20.5-45$ & 1185 & 48 & & 1574 & 64 & & 934 & 38 \\
$0-45$ & 2149 & 48 & & 2857 & 64 & & 1718 & 38
\end{tabular}

Point A refers to western syntaxis $\left(33.5^{\circ} \mathrm{N}, 74^{\circ} \mathrm{E}\right)$, point B refers to eastern syntaxis $\left(28^{\circ} \mathrm{N}, 96^{\circ} \mathrm{E}\right)$, and point $\mathrm{C}$ refers to the southern end of western limb $\left(25^{\circ} \mathrm{N}, 66^{\circ} \mathrm{E}\right)$. Distance is in kilometers; average velocity is in milllimeters per year.

TABLE 3. Velocity Azimuth, Obliquity, and Shortening Velocity

\begin{tabular}{|c|c|c|c|c|c|c|c|c|c|}
\hline \multirow[t]{2}{*}{ Age, Ma } & \multicolumn{3}{|c|}{$\mathrm{A}$} & \multicolumn{3}{|c|}{ B } & \multicolumn{3}{|c|}{$\mathrm{C}$} \\
\hline & V & 0 & $S$ & $\mathbf{V}$ & 0 & $\mathbf{S}$ & $\mathrm{V}$ & 0 & $\mathbf{S}$ \\
\hline $0-7$ & 5 & 5 & 45 & 17 & -5 & 55 & 11 & 63 & 18 \\
\hline $7-20.5$ & -13 & 33 & 40 & 4 & 24 & 61 & -6 & 35 & 30 \\
\hline $20.5-49$ & 0 & 35 & 40 & 12 & 26 & 58 & +6 & 30 & 33 \\
\hline
\end{tabular}

$\mathrm{V}$ is velocity azimuth in degrees east; $\mathrm{O}$ is obliquity in degrees measured with respect to perpendicular to $A B$ for $A$ and $B$, positive to the west and to perpendicular to $B C$ for $C$, positive to the north; $S$ is shortening velocity in millimeters per year and equals velocity $x$ cos (obliquity).

TABLE 4. Surface Loss and Rate of Surface Loss

\begin{tabular}{|c|c|c|c|c|c|c|c|c|}
\hline & \multicolumn{2}{|c|}{$0-7 \mathrm{Ma}$} & \multicolumn{2}{|c|}{$7-20.5 \mathrm{Ma}$} & \multicolumn{2}{|c|}{$20.5-45 \mathrm{Ma}$} & \multicolumn{2}{|c|}{$0-45 \mathrm{Ma}$} \\
\hline & Loss & Rate & Loss & Rate & Loss & Rate & Loss & Rate \\
\hline A B & 7.7 & 1.1 & 15.5 & 1.15 & 27.3 & 1.11 & 50.5 & 1.12 \\
\hline B C & 2.0 & 0.28 & 5.8 & 0.43 & 10.6 & 0.44 & 18.4 & 0.41 \\
\hline
\end{tabular}

Surface loss is in unit of $10^{5} \mathrm{~km}^{2}$; rate is in unit of $10^{5} \mathrm{~km}^{2} \mathrm{~m} . \mathrm{y} .^{-1}$ through great circles $\mathrm{AB}$ and $\mathrm{BC}$, respectively. 
The distances between the positions of $A$ and $B 45$ m.y. ago ( $A^{\prime}$ and $B^{\prime}$ in Figure 1$)$ and this assumed Asian boundary are then 600 and $1300 \mathrm{~km}$, respectively. Coward et al. [1987] have measured a minimum amount of shortening of about $500 \mathrm{~km}$ near $A$ in the Western Himalayas. Thus India should be extended by at least $500 \mathrm{~km}$ to the north near $\mathrm{A}^{\prime}$. Dewey et al. [1989] believe that as much as $1000 \mathrm{~km}$ may have been absorbed by shortening of Indian crust within the Himalayas. Molnar [1987], following Lyon-Caen and Molnar [1985], has estimated the post-Oligocene average Himalayan rate of shortening near $75^{\circ}-80^{\circ} \mathrm{E}$ at $18 \pm 7 \mathrm{~mm} \mathrm{yr}^{-1}$ or 450 $\pm 175 \mathrm{~km}$ since $25 \mathrm{~m} . \mathrm{y}$. ago. Using the same rate, the shortening since $45 \mathrm{Ma}$ would be $810 \pm 315 \mathrm{~km}$. We take the minimum amount shortening within the Himalayas as $600 \mathrm{~km}$. Then, this minimum configuration of Greater India implies that about $20 \mathrm{x}$ $10^{5} \mathrm{~km}^{2}$ have since disappeared by shortening or underplating. In this configuration, initiation of collision occurred 45 m.y. ago near $A^{\prime}$ with the minimal Asian configuration discussed above. However, near B', there was still a $700 \mathrm{~km}$ oceanic gap.

Powell et al. [1988] have argued that one can get some fairly precise information on the actual shape of the eastern Greater India configuration from the original fit of this margin with Australia. The fit they propose indicates that at the level of the present Himalayas, India could not extend to the east of the present $95^{\circ} \mathrm{E}$ longitude. Veevers and Powell [1979] argued further that the present structure of the Australian margin suggests that Greater India extended as far north as the Cape Range Fracture Zone, on the Australian eastern margin, corresponding to $40^{\circ} \mathrm{N}, 93.5^{\circ} \mathrm{E}$ in present India coordinates. This point is now situated on the northernmost boundary of Tibet and would imply that Greater India extended $1300 \mathrm{~km}$ north of the Indus Suture Zone near the eastern syntaxis. Figure 1 shows this eastern boundary of Greater India according to Powell et al. [1988]. The corresponding surface of Greater India beyond the Indus Suture Zone is $25.8 \times 10^{5} \mathrm{~km}^{2}$. This maximal configuration of Greater India would have achieved full collision $45 \mathrm{~m}$.y. ago with the minimal former configuration of Asia shown in Figure 1.

We have seen that collision should be complete by the end of middle Eocene, some 42 m.y. ago because no neritic limestones were deposited on the Indian shelf beyond this date and because there is no more significant change in the Indian ocean spreading pattern after anomaly 18 (43 Ma). A 3 m.y. difference corresponds to a northward Indian motion of $180 \mathrm{~km}$. However, collision is probably tectonically significant when the distance between the edges of the two shelves is less than $200-300 \mathrm{~km}$. For example, compressive tectonics already effect the mantle in the Mediterranean Sea between Crete and Lybia, which are about $300 \mathrm{~km}$ apart [Taymaz et al., 1991], and by the time the space is reduced to 100 $\mathrm{km}$, there might be very little if any sea left there. Consequently, a maximum oceanic gap of about 300 km may have existed near B' 45 m.y. ago, and the remaining $400 \mathrm{~km}$ left open by the minimal configurations for Greater India and former Asia must be filled either by Indian crust, as in the solution of Powell et al. [1988] or by Asian crust, as in the solution of Tapponnier et al. [1986] and Dewey et al. [1989].

In these latter two papers, the southern boundary of Asia is drawn between point $C$ in Figure 1 and the Mentawei islands near $5^{\circ} \mathrm{S}, 100^{\circ} \mathrm{E}$. The corresponding surface of Asia which has disappeared by shortening or expulsion is then $5.25 \times 10^{6} \mathrm{~km}^{2}$. However, with this configuration, the minimal Greater India would have begun its collision with Asia about 55 m.y. ago which is too early by 10 million years. Consequently the southern boundary of India must have been much closer to the minimal configuration chosen in Figure 1.

As a result, the range of possibilities to achieve full collision 45 m.y. ago along $A B$ is relatively small. The total surface loss is $68-69 \times 10^{5} \mathrm{~km}^{2}$ (see Table 4), but about $10 \%\left(6.5 \times 10^{5} \mathrm{~km}^{2}\right)$ correspond to oceanic space in front of $\mathrm{B}^{\prime} \mathrm{C}^{\prime}$ on the western border of India. Consequently, about $62 \times 10^{5} \mathrm{~km}^{2}$ of continental shortening should be given by a combination of Greater India surface shortening north of the Indus Suture Zone and Asian shortening. As argued above, this figure could be slightly reduced because collision might not have been complete everywhere between A and B 45 m.y. ago and because, if Powell et al. [1988] are correct, the eastern boundary of Greater India in its northern portion was situated to the east of flow line B'B (see Figure 1).

We conclude that the total amount of continental shortening and (or) expulsion since $45 \mathrm{Ma}$ lies somewhere between $57 \times 10^{5} \mathrm{~km}^{2}$ and $62 \times 10^{5} \mathrm{~km}^{2}$ with $11.5 \times 10^{5} \mathrm{~km}^{2}$ across $\mathrm{AC}$ and the balance across $A B$. We conclude further that Asian shortening has been between $34.5 \times 10^{5} \mathrm{~km}^{2}$ and 42 $x 10^{5} \mathrm{~km}^{2}$ and Greater Indian shortening between 20 $x 10^{5} \mathrm{~km}^{2}$ and $25.8 \times 10^{5} \mathrm{~km}^{2}$. The ratio of Greater India versus total shortening varies between 30 and $45 \%$.

The estimates of total continental shortening are fairly robust as they mostly depend on the initiation time of collision along the Himalayas $(45 \pm 2 \mathrm{Ma}$ ) because the kinematics of India relative motion are sufficiently well known. This will now be demonstrated by comparing our solution to the one proposed by Dewey et al. [1989].

\section{Comparison With the Solution Proposed by Dewey et al. [1989]}

We have made the same computations using the kinematic solution proposed by Dewey et al. [1989]. Dewey et al. use the Haq et al. [1987] chronology, which puts anomaly 20 at $44.7 \mathrm{Ma}$ instead of 46.2 $\mathrm{Ma}$ in the scale of Kent and Gradstein [1986]. Using their chronology, the surface shortening across $A B$ since $45 \mathrm{Ma}$ is $5.2 \times 10^{6} \mathrm{~km}^{2}$ and is $5 \times 10^{6} \mathrm{~km}^{2}$ if 
we use the Kent and Gradstein scale. Thus the surface shortening in both solutions is the same provided we use the same time scale.

The total distances traveled by $\mathrm{A}$ and $\mathrm{B}$ with respect to Asia since $45 \mathrm{Ma}$ are 2290 and $3040 \mathrm{~km}$ in the Dewey et al. solution compared to 2150 and 2860 in our solution. The small differences result from a more complex and detailed path for the Dewey et al. solution as they have five intermediate positions of India between $45 \mathrm{Ma}$ and now compared to two in our solution. However, their resulting velocities show abrupt changes at anomaly 8 ( $30 \%$ decrease), anomaly 5 (5\% increase), and anomaly 3 (30\% decrease again) which may simply reflect excessive detail in their kinematic solution. Note that the figures given here are different from the ones published by Dewey et al., which appear to be inexact.

Concerning the partitioning between shortening within Asia and shortening of the northern extension of Greater India, Dewey et al. [1989] limit India to the north to the Main Boundary Thrust in their reconstruction. They should have added to India the present width of the Himalayas $(250$ to $300 \mathrm{~km}$ ) plus the shortening of the Himalayas which they consider to be about $1000 \mathrm{~km}$. Then, the northern boundary of Greater India would have lain 1200 to $1300 \mathrm{~km}$ further north than drawn on their recontructions and collision with the former configuration of Asia they adopt would have occurred much too early as discussed above.

\section{Position of Southern Tibet From Paleomagnetic Data}

The range of former Asian configurations previously considered acceptable indicates about $1250 \mathrm{~km}$ to $1900 \mathrm{~km}$ of latitudinal shortening between southern Tibet and Asia at the longitude of Lhasa. Achache et al. [1984] obtained a paleolatitude near Lhasa for Aptian-Albian (Takena formation) of $12.5^{\circ} \mathrm{N} \pm 3^{\circ}$. A similar paleolatitude was found for Western Tibet for the same period [Chen et al., 1991]. Using the $110-100 \mathrm{Ma}$ average paleomagnetic pole of Eurasia of Besse and Courtillot (1991), the latitudinal shortening between southeastern Tibet and Asia is $1300 \mathrm{~km}$ and between Southern Tibet and Asia 1500 which fits our conclusions. On the other hand, the Paleocene pole proposed by Achache et al. [1984] gives a larger 2000 to $2500 \mathrm{~km}$ amount of latitudinal shortening between southern Tibet and Asia since 60-50 Ma. This larger shortening is beyond the range of permissible Asian shortening given by our reconstruction. However, as pointed out by Achache et al., this result would have implied a relative latitudinal southward motion of Tibet with respect to Asia between 110-100 Ma and 60-50 Ma, at a time when the northern Lhasa block was already firmly accreted to Northern Tibet [Chang et al., 1986].

\section{TOPOGRAPHY OF ASIA AND SHORTENING}

We now investigate whether the Asian topography around India can account for the surface loss computed in the previous section, assuming that the volume of crust is conserved and that jts density is unchanged. We estimate quantitatively the distribution of topography using the ETOPO 5 data base which gives an average altitude for each $5^{\prime}$ x $5^{\prime}$ rectangle. Figure 2 shows the areas over which these estimates have been made. Zone 1 includes Tibet and the Himalayas but extends somewhat beyond the base of the steep slope. The area of $4.1 \times 10^{6} \mathrm{~km}^{2}$ thus is larger than the actual area of high plateau which explains the relatively small average elevation of $3.63 \mathrm{~km}$. Zone 2 includes other regions of compressive tectonics considered to be related to the indentation of Asia. We have excluded to the east regions of extension and anomalously thin lithosphere in eastern China, around Shan Xi [Ma et al., 1984; $\mathrm{Ma}$ and $\mathrm{Wu}, 1987]$ and in Mongolia, southwest and south of the Baiikal [Zorin et al., 1990]. Zone 3, finally, includes the western limb, west of $71^{\circ} \mathrm{E}$.

\section{Qualitative Description}

Figure 3 shows 10 topographic profiles located in Figure 2 and oriented $N 10^{\circ} \mathrm{E}$, parallel to the present motion vector. The topography over India and to the north in Siberia is small. The average altitude of India south of the Himalayas is about $400 \mathrm{~m}$, and the average altitude of the Siberia plain east of the Baikkal region is less than $250 \mathrm{~m}$.

The Tibet massif stands out clearly but cannot be differentiated from the Himalayas. Both have the same base altitude of about $5000 \mathrm{~m}$ as was noted by Bird [1978]. Several authors [Tapponnier and Molnar, 1976; Bird, 1978; England and Houseman, 1986; Zhao and Morgan, 1985; Molnar and LyonCaen, 1988] have discussed the formation of the uniform altitude of this high-standing plateau and have shown that it involves lateral spreading, most probably within the lower crust [Bird, 1991]. That lateral spreading occurs is suggested by the fact that the Tibetan Plateau extends about $600 \mathrm{~km}$ to the southeast beyond the eastern syntaxis [Dewey et al., 1989](see Figure 2 and profile 7 in Figure 3).

Finally, the width of the Tibetan Plateau increases from about $400 \mathrm{~km}$ (profiles 1 and 2) to 1100 (profiles 5 and 6 ) in a relatively smooth fashion from the western to the eastern syntaxis. This is a $175 \%$ increase whereas the increase in total kinematic shortening computed in the previous section is only about $40 \%$. If Tibet is indeed the result of crustal shortening and (or) underthrusting, then there must be a drastic redistribution toward the east of the crust north of the indenter. Note, however, that because of the counterclockwise rotation of India (see Figure 1), the western syntaxis has migrated westward about $300 \mathrm{~km}$ with respect to Asia, this motion probably being absorbed in dextral faults such as the Karakorum fault [e.g., Armijo et al., 1986, 1989]. This westward migration of the western syntaxis does not agree with the hypothesis of Treloar and Coward [1991], who propose that the western syntaxis, which first indented Asia, was locked into 


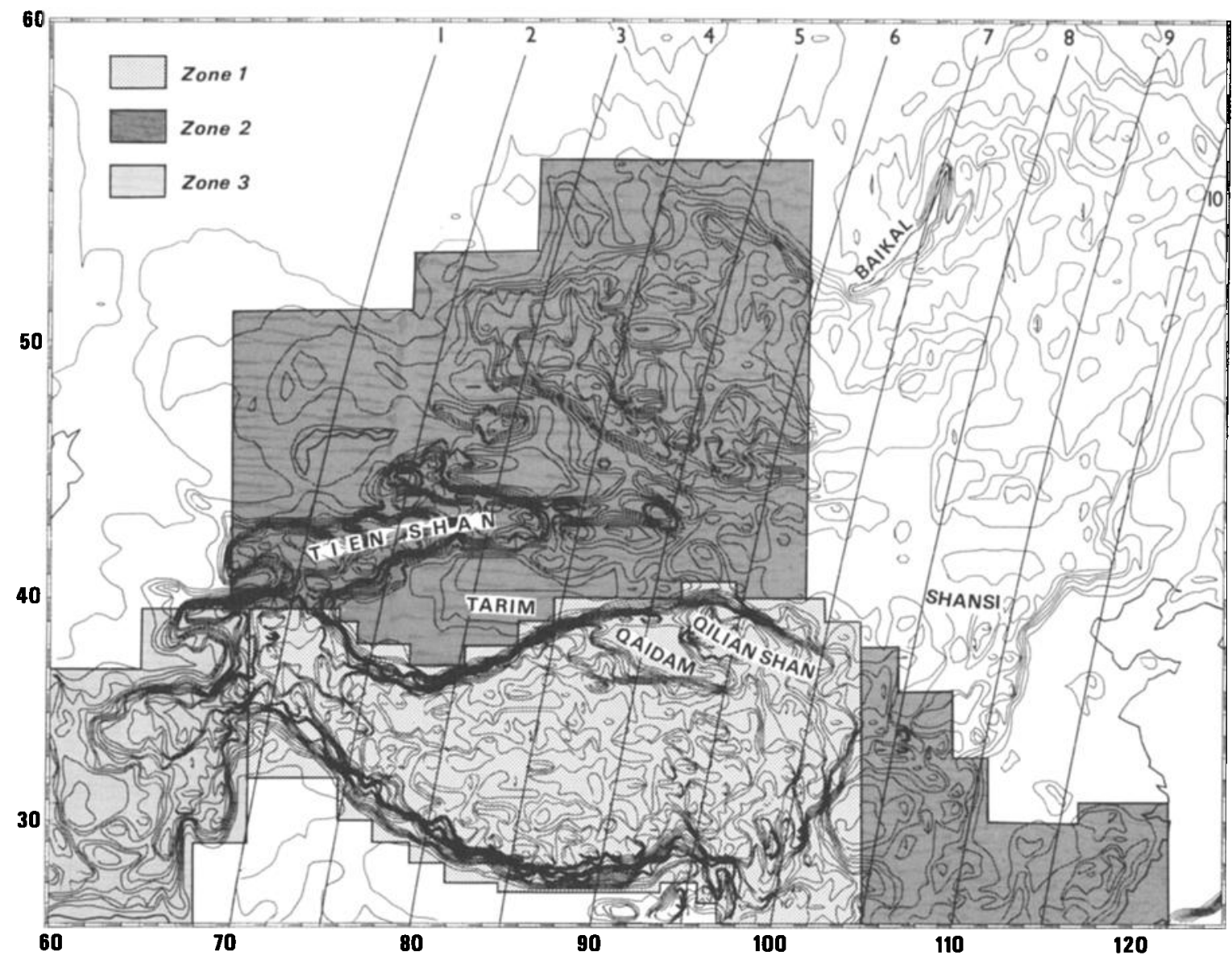

Fig. 2. Base topographic map used for the estimates of volume of topography after the ETOPO5 data base. Contours are every $200 \mathrm{~m}$. A different pattern identifies the three zones: zone 1, Tibet; zone 2, west of $71^{\circ} \mathrm{E}$; and zone 3 to the north and east. Locations of the 10 topographic profiles shown in Figure 3 are indicated.

its collision position. It could account on the other hand for a small part of the sharp westward decrease in width of Tibet.

To the north, two massifs stand out clearly, the Tien Shan (profiles 1 to 3 ) and the Altaï (profiles 3 to 6). That these massifs are related to the Indian indentation is now well established [Molnar and Tapponnier, 1975; Tapponnier and Molnar, 1976, 1977]. The Tien Shan could be considered as a northward extension of Tibet beyond the undeformed and apparently quite rigid Tarim basin (Figure 2 and profile 3 in Figure 3). In the same way, but on a smaller scale, the Qilian Shan appears to be a northward extension of Tibet beyond the small Qaidam basin (Figure 2 and profiles 5 and 6). The Altaï, on the other hand, has a different structure as it is dominated by strike-slip faulting resulting in a net NNE crustal shortening [Tapponnier and Molnar, 1979].

We exclude from our consideration northeastern China and Mongolia east of the Altai massif because they are regions affected by extension and because the lithosphere is abnormally thin there, as discussed above. Consequently, their average $1000 \mathrm{~m}$ elevation there may be due, at least in part, to the presence of a hotter mantle below.

\section{Quantitative Description}

That the topography discussed above is mostly the result of crustal thickening is beyond doubt. The thickness of crust from India to Tibet increases from $37-38 \mathrm{~km}$ south of the Himalayas [e.g., Sharma et al., 1991] to up to $75 \mathrm{~km}$ below Tibet [Hirn et al., 1984]. The average thickness of the Tibet crust is 70 km (Zhao et al., 1991) for an average topographic elevation of $5 \mathrm{~km}$. The crust is about $35 \mathrm{~km}$ thick in southeastern China [Zhao et al., 1991]. A generalized isopach crustal thickness map of China based on gravity data is in agreement with these seismological determinations [e.g., Tan Tong Kie, 1987]. We can consequently assume a simple linear relationship between anomalous crustal thickness $\Delta \mathrm{T}$ and topographic elevation $\mathrm{h}$ :

$$
\mathrm{h}=\Delta \mathrm{T} / 7
$$



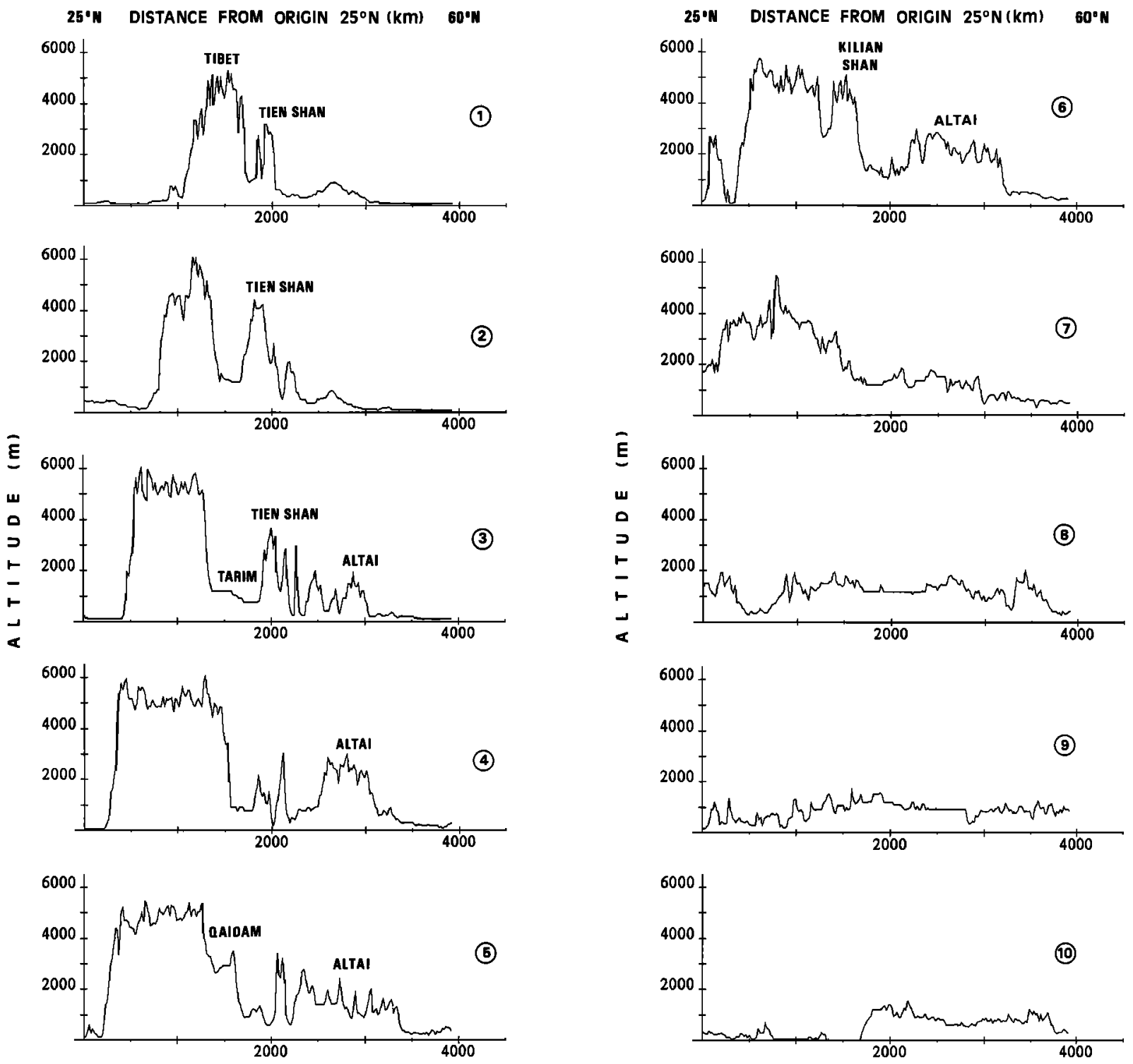

Fig. 3. Ten topographic profiles located in Figure 2 shown with a vertical exaggeration of 200. Note the low elevation in India to the south and Siberia to the north, the eastward widening of Tibet, and the progressive transfer of topography from Tien Shan to the west to Altai to the east. Note also the eastward extension of Tibet to profile 7, beyond the eastern Himalayan syntaxis, whereas the Altai topography does not extend that far eastward. Finally, note the relatively uniform $1000 \mathrm{~m}$ altitude of the profiles east of profile 7 in regions mostly dominated by extension.

where $\Delta \mathrm{T}=(\mathrm{T}-35) \mathrm{km}$ is the excess crustal thickness over $35 \mathrm{~km}$, the adopted thickness for 0 elevation. This relationship gives a thickness of 38 $\mathrm{km}$ for India (elevation $400 \mathrm{~m}$ ) and $70 \mathrm{~km}$ for Tibet (elevation $5 \mathrm{~km}$ ) in agreement with the data.

With this relation, the cross-sectional surface $S$ of the topography above sea level along a profile can be converted in the length of shortening $\Delta \mathrm{L}$ which would have produced it, assuming plane strain shortening along the profile. We have

$$
\Delta \mathrm{L}=\mathrm{S} / 5
$$

In the same way, the volume $V$ of the topography above sea level within a given area can be converted in the surface elimination $\Delta \mathrm{A}$ necessary to produce it. We have

$$
\Delta \mathrm{A}=\mathrm{V} / 5
$$

In the following, the statistics we give along profiles are in kilometers of length of shortening. We do this because square kilometers of surface 
topography along a profile are difficult to relate simply to crustal shortening. However, although our estimates of surface $S$ are exact, the conversion in $\Delta \mathrm{L}$ is only as valid as the assumptions we make. We will discuss the validity of these assumptions later.

Figure 4 shows estimates of equivalent linear shortening obtained along longitudinal profiles every 5'. The estimates are made over zone 1 (Tibet, middle curve) and zone 2 (Altaï, Tien Shan and South China, lower curve) (see Figure 2 for the localization of the zones). The equivalent shortening increases linearly from $71^{\circ} \mathrm{E}$ to $90^{\circ} \mathrm{E}$ from 600 to $1800 \mathrm{~km}$. Then there is a relatively sharp drop to $1500 \mathrm{~km}$ at $95^{\circ} \mathrm{E}$ due to the Qaidam basin, an increase again to a maximum of nearly $2000 \mathrm{~km}$ near $98^{\circ} \mathrm{E}$, and finally a very steep drop to less than $400 \mathrm{~km}$ beyond $105^{\circ} \mathrm{E}$.

Two obvious characteristics of this distribution should be noted. First, there is a broad maximum extending east of the eastern syntaxis between $90^{\circ}$ and $100^{\circ} \mathrm{E}$. It is 3 times larger than the value at the western syntaxis. Second, there is a regular linear increase in the amount of shortening from west to east. This strongly asymmetrical distribution is different from the one expected if linear shortening in front of the indenter were exactly related to its relative motion. Then, one would expect a $40 \%$ sinusoïdal increase from $71^{\circ}$ to $95^{\circ} \mathrm{E}$ and an abrupt decrease beyond these two points instead of the $200 \%$ linear

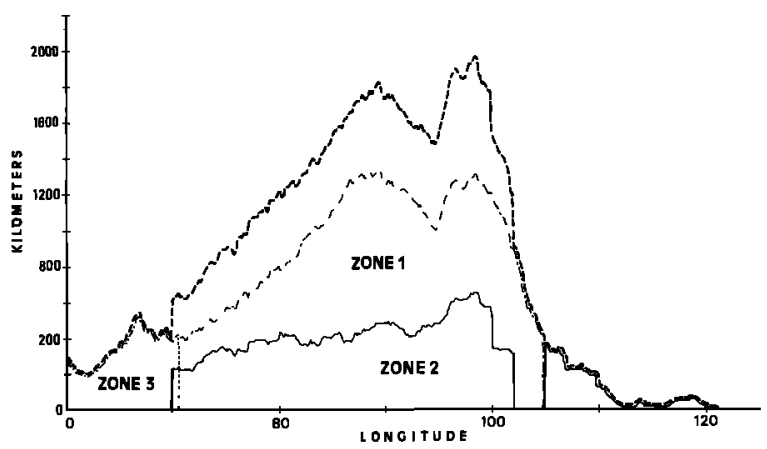

Fig. 4. Equivalent linear shortening in kilometers versus longitude computed for each N-S profile in zone 2 (lower curve), zone 1 (Tibet, middle curve), and combined zones 1,2 , and 3 (upper curve). The shortening is assumed to be purely N-S. There is no correction for nonzero $45 \mathrm{Ma}$ elevation and post-45 Ma erosion. See text for discussion. increase and the extension of the maximum east of $95^{\circ} \mathrm{E}$.

Consider now the shortening corresponding to the excess crust outside of Tibet, in zone 2 (lower curve on Figure 4), essentially within the Tien Shan and Altai massifs. It increases relatively regularly from about 250-270 to a maximum of $500-600$ near $98^{\circ} \mathrm{E}$. Beyond $100^{\circ} \mathrm{E}$, the sharp drop results from the exclusion of regions of thin lithosphere and extension. However, even if one included these regions, the curve would continue to decrease progressively. Thus the maximum, north of Tibet, is centered at the same longitude as for Tibet. The increase from west to east is also approximately linear and in a ratio of about 2 . Finally, the transition beetween Tien Shan and Altaï (see Figure 2) is impossible to detect in Figure 4. Thus there is a progressive shift in topography from Tien Shan to Altaï across the overlap region.

Table 5 gives the volumes of topography over the three areas. The total amount of $23 \times 10^{6} \mathrm{~km}^{3}$ is identical to the value found by England and Houseman [1986] over a similar area. Table 6 gives the corresponding surface of shortening assuming a zero topography base level prior to collision. With the relation adopted above, the surface in square kilometers is 0.2 of the volume in cubic kilometers. Three millions square kilometers of surface elimination are stored in the crust of Tibet compared to $1.2 \mathrm{~km}^{2}$ in zone 2 north of Tibet and $0.35 \mathrm{~km}^{2}$ in zone 3 for a total of $4.55 \times 10^{6} \mathrm{~km}^{2}$. Thus two thirds of the excess crust due to shortening is stored within Tibet and one fourth north of it in Tien Shan and Altaï. This total figure of $4.55 \times 10^{6} \mathrm{~km}^{2}$ should be compared to the $5.7 \times 10^{6}$ to $6.2 \times 10^{6} \mathrm{~km}^{2}$ surface elimination obtained from kinematic considerations in the first section.

England and Houseman [1986] used a more complex relation between topography and crustal thickness which takes into account isostatic balance to the base of the lithosphere. They use two extreme cases. In a first one, their solution gives a $25.3 \mathrm{~km}$ crust for zero elevation and $64 \mathrm{~km}$ for $5 \mathrm{~km}$ elevation. This solution does not fit the Asian data. In a second one, they obtain 34.5 and $71.5 \mathrm{~km}$, respectively, which are close to the values we choose. Thus their second solution best fits the present Asian data and gives results close to ours.

\section{Effects of Preexisting Topography and Erosion}

However, we need to discuss the limitations of the rather drastic hypothesis we made to convert

TABLE 5. Volumes of Topography

\begin{tabular}{lcccc}
\hline & Zone 1 & Zone 2 & Zone 3 & Total \\
\hline Surface area $\left(10^{6} \mathrm{~km}^{2}\right)$ & 4.13 & 5.24 & 1.30 & 10.67 \\
Average altitude $(\mathrm{km})$ & 3.63 & 1.17 & 1.29 & 2.14 \\
Volume $\left(10^{6} \mathrm{~km}^{3}\right)$ & 15.00 & 6.12 & 1.68 & 22.80 \\
\hline
\end{tabular}


topography into surface loss because we have ignored any preexisting topography and we have also ignored erosion. These two effects act in opposite directions, and we now try to estimate then.

The present base level of topography in India, to the south, is about $400 \mathrm{~m}$ and in Siberia, to the north, about $250 \mathrm{~m}$ as discussed above. Thus one should use a minimum base level of 250 to $400 \mathrm{~m}$. However, one might expect a somewhat higher elevation in the center of the former continent. Yet, to the north of Tibet, in Tien Shan and Altaï, the topography is considered to have been a peneplain until late Oligocene, presumably as in the Siberian plains today [Zonenshain and Savostin, 1981]. Thus we assume a base level of $500 \mathrm{~m}$ (corresponding to a crustal thickness of $38.5 \mathrm{~km}$ ) in zone 2 . We do the same for zone 3 .

Tibet was subaerial $45 \mathrm{~m} . y$. ago as the last marine sediments deposited there are Mid-Cretaceous [e.g., Mercier et al., 1987]. We mentioned earlier that an Andean type margin was active on its southern margin during Upper Cretaceous and that volcanic activity continued until the collision. However, the Paleocene-Eocene volcanics were deposited on an erosion surface, and the climate was warm, wet subtropical to tropical [Mercier et al., 1987]. It is considered that the altitude was definitely less than $1000 \mathrm{~m}$ [e.g., Dewey et al., 1988]. In northern Tibet, Paleogene red beds indicate an arid subtropical climate believed to correspond to a low altitude. One could then conclude that the average altitude was $1000 \mathrm{~m}$ or smaller to the south and a few hundreds of meters to the north. Thus the average altitude of Tibet was possibly more than 500 but most probably less than $1000 \mathrm{~m}$. This conclusion is more conservative than that of most previous authors [e.g., England and Houseman, 1986; Mercier et al., 1987; Dewey et al., 1989], who assumed an average elevation equal or smaller than $500 \mathrm{~m}$ for Tibet prior to collision.

Table 6 shows estimates corrected for a $500 \mathrm{~m}$ base level in zones 2 and 3 and for both a $500 \mathrm{~m}$ and a $1000 \mathrm{~m}$ base level in zone 1 . The total area loss then decreases by 30 to $40 \%$ with respect to the zero base level case. Note that the computations have been made assuming local shortening of the crust. Slightly larger figures would be obtained for underthrusting by a normal thickness crust.
We next consider the effect of erosion. Most of the debris of the Himalayan chain lies within the Bengal and Indus fans and within the Ganga basin. Tibet itself has not been affected by a large amount of erosion [Zhao and Morgan, 1985; England and Houseman, 1986]. Copeland and Harrison [1990] estimate $1.5 \times 10^{7}$ to $2.0 \times 10^{7} \mathrm{~km}^{3}$ of sediments to be present in the Bengal fan. The map of post-Eocene sediments in the Bengal fan published by Curray [1991] appears to indicate a value close to $1.25 \times 10^{7}$ $\mathrm{km}^{3}$. There is about one fifth that amount in the Indus fan and about $10^{6} \mathrm{~km}^{3}$ in the Ganga basin [Lyon-Caen and Molnar, 1983]. Thus a total of $19 \mathrm{x}$ $10^{6}$ to $25 \times 10^{6} \mathrm{~km}^{3}$ of sediments appears to be now present in these fans and basin. Taking into account a $10 \%$ decrease in density of the sediments with respect to whole rocks [Lyon-Caen and Molnar, 1983], this amount could be produced by the erosion of $0.45 \times 10^{6}$ to $0.60 \times 10^{6} \mathrm{~km}^{2}$ of a $38.5 \mathrm{~km}$ thick crust. We assume that an additional amount equivalent to $0.10 \times 10^{6}$ to $0.15 \times 10^{6} \mathrm{~km}^{2}$ of surface loss fills the Neogene basins north of Tibet. Then, the total amount of surface loss corresponding to the eroded sediments is about $0.6 \times 10^{6}$ to $0.75 \times 10^{6}$ $\mathrm{km}^{2}$. We have ignored sediments from the Himalayas now stored within the Makran accretionary prism and within the Indo-Burman ranges. On the other hand, the estimate of Copeland and Harrison [1990] appears quite high compared to the latests estimate by Curray [1991]. Thus we estimate that the amount of erosion is unlikely to be significantly larger than the estimate we give.

Table 6 then shows that the corrected total amount of surface loss varies from $5.1 \times 10^{6}$ to $5.3 \times 10^{6}$ $\mathrm{km}^{2}$ for zero base level (highly unlikely), to $3.2 \mathrm{x}$ $10^{6}$ to $3.4 \times 10^{6}$ for $500 \mathrm{~m}$ base level for zones 2 and 3 and $1000 \mathrm{~m}$ base level for zone 1 . For the prefered case of $500 \mathrm{~m}$ base level everywhere, we obtain 3.75 $\times 10^{6}$ to $3.95 \times 10^{6} \mathrm{~km}^{2}$ to be compared to $5.7 \times 10^{6}$ to $6.2 \times 10^{6}$ computed from kinematic considerations. Consequently, even in the highest and unrealistic zero base level estimate, there is still a deficit of $10 \%$ between the shortening stored in the topography and the kinematic shortening.

TABLE 6. Area Loss Corresponding to Excess Crust

\begin{tabular}{lccccc}
\hline & Zone 1 & Zone 2 & Zone 3 & Total & Total + Erosion \\
\hline Zero base level & 3.00 & 1.22 & 0.34 & 4.56 & $5.1-5.3$ \\
500 m base level (all & 2.35 & 0.64 & 0.19 & 3.18 & $3.75-3.95$ \\
zones)* & & & & & \\
500 m (II, III) & 1.81 & 0.64 & 0.19 & 2.64 & $3.20-3.40$ \\
1000 m (I) & & & & & \\
\hline
\end{tabular}

Area loss is in unit of $10^{6} \mathrm{~km}^{2}$.

* Crust is $38.5 \mathrm{~km}$ thick for $500 \mathrm{~m}$ topography.

\# Crust is $42 \mathrm{~km}$ thick for $1000 \mathrm{~m}$ topography. 
Depending on the base level chosen, somewhere between $500 \mathrm{~m}$ everywhere and $1000 \mathrm{~m}$ in Tibet, the deficit is $1.75 \times 10^{6}$ to $3.00 \times 10^{6} \mathrm{~km}^{2}$. To account for this deficit without extrusion, Dewey et al..[1989] have proposed that the continental crust entering the Himalayan collision zone during the early collision (upper Eocene to perhaps Oligocene) was much thinner than the present $38.5 \mathrm{~km}$ crust. If this were true, the deficit can indeed be reduced and even altogether eliminated. However, if the shortened upper Eocene to Oligocene crust was very thin, the expected paleo-water depth would be at least 1 to 2 $\mathrm{km}$. However, we have seen that there is no evidence of marine sediments older than $45 \mathrm{Ma}$ in the Himalayas and that the $45 \mathrm{Ma}$ marine sediments were deposited in shallow seas. We thus assume that both Indian and Tibetan crusts implicated in the collision were subaerial and consequently of "normal" thickness at times later than $45 \mathrm{Ma}$. The computed deficit presumably corresponds to lateral extrusion or to crust transferred to the mantle by eclogitization.

\section{Longitudinal Variation in Deficit}

We may try to go further and estimate the deficit as a function of longitude comparing the estimates of equivalent total linear shortening (shown in Figure 4) to the estimates of kinematic shortening made in the first section. We correct for erosion and distribute the $0.75 \times 10^{6} \mathrm{~km}^{2}$ corresponding area lost between $65^{\circ}$ and $105^{\circ} \mathrm{E}$ adding uniformly $200 \mathrm{~km}$ to the profiles between $72.5^{\circ}$ and $102.5^{\circ} \mathrm{E}$ but only $100 \mathrm{~km}$ west and east of these longitudes. Figure 5 shows this comparison both for the unlikely $0 \mathrm{~m}$ base level, which is an absolute maximum, and for the most probable $500 \mathrm{~m}$ base level, considered most likely.

There is a fairly uniform deficit of $600 \mathrm{~km}(0 \mathrm{~m}$ base level) to $950 \mathrm{~km}(500 \mathrm{~m}$ base level) west of $96^{\circ} \mathrm{E}$ and a large excess to the east of it. The amount of the eastern excess shortening is $75 \%$ of the western rather uniform deficit in the first case but only $33 \%$ in the second one. A simple interpretation is that the western deficit of 600 to $950 \mathrm{~km}$ has been transferred east of the eastern syntaxis. Part of this transfer resulted in eastward growth of Tibet, but the main part (probably about two thirds) corresponded to net lateral extrusion of continental crust. However, we still have to consider more closely the difficult problem of the amount of shortening absorbed in the Himalayas.

\section{SHORTENING IN THE HIMALAYAS}

Between $74^{\circ}$ and $96^{\circ} \mathrm{E}$, the Himalayas are limited by two concentric small circles, a southern one along the Main Boundary Thrust and a northern one along the Indus Suture Zone [e.g., Crawford, 1982, quoted in Klootwijk et al., 1985]. A best fit gives a center of the small circles near $42^{\circ} \mathrm{N}, 89^{\circ} \mathrm{E}$. The average distance between the circles is $2.4^{\circ}(265 \mathrm{~km})$ and the length of the arc is $2400 \mathrm{~km}$. The surface of the Himalayas between $74^{\circ}$ and $96^{\circ} \mathrm{E}$ is then $5.9 \mathrm{x}$

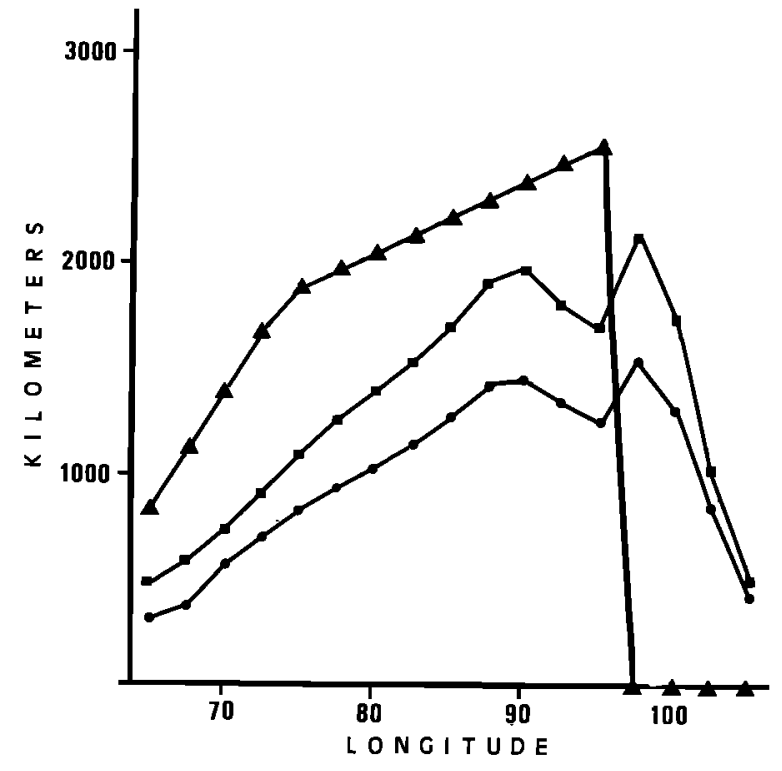

Fig. 5. The equivalent linear shortening as in Figure 4 is shown here corrected for erosion and for the $\mathbf{4 5}$ Ma topographic base level. It is compared to the expected linear shortening from kinematics (upper curve with triangles). Two cases are shown for two different topographic base levels at $45 \mathrm{Ma}$ : the $0 \mathrm{~m}$ case (curve with squares) and the $500 \mathrm{~m}$ one (curve with small circles). See text for discussion.

$10^{5} \mathrm{~km}^{2}$. West of $74^{\circ} \mathrm{E}$ and east of $96^{\circ} \mathrm{E}$, we estimate an additional $2 \times 10^{5} \mathrm{~km}^{2}$ of surface for a total of 7.9 $x 10^{5} \mathrm{~km}^{2}$. Half of the chain is at Tibet altitude, the other half shows an increase from 500 to $5000 \mathrm{~m}$. Thus the average altitude is $3.85 \mathrm{~km}$.

The excess topography above $500 \mathrm{~m}$ is equivalent to a surface loss of $4.8 \times 10^{5} \mathrm{~km}^{2}$. We have to take into account the additional $18 \times 10^{6}$ to $24 \times 10^{6} \mathrm{~km}^{3}$ of sediments stored in the plains and fans which come almost entirely from the erosion of the Himalayas. This represents 23 to $30 \mathrm{~km}$ of average erosion over the whole chain. Then, the surface loss is approximately doubled to $10^{6} \mathrm{~km}^{2}$. This is equivalent to $300-350 \mathrm{~km}$ of average linear shortening. Consequently, as noted by Lyon-Caen and Molnar [1983], if the crust involved in the shortening of the Himalayas has been conserved within the chain, except for the part eroded, it is impossible to account for more than about $350 \mathrm{~km}$ of shortening.

Lyon-Caen and Molnar [1985] have used drill hole results in the Ganga plain to determine a rate of underthrusting of $10-15 \mathrm{~mm} \mathrm{yr}^{-1}$ in the last $10-20$ m.y. between $76^{\circ} \mathrm{E}$ and $81^{\circ} \mathrm{E}$. Molnar [1987], taking into account $5 \mathrm{~mm} \mathrm{yr}^{-1}$ of probable strain within the belt itself increased the estimate to $18 \pm 7 \mathrm{~mm} \mathrm{yr}^{-1}$ which is in the upper range of our estimate and 
equivalent to $810 \pm 315 \mathrm{~km}$ since $45 \mathrm{Ma}$ as discussed earlier. If the crust involved in the shortening has been conserved within the mountain belt (except for erosion), the total shortening barely accounts for the last $20 \mathrm{~m} . \mathrm{y}$. and no pre-Miocene crust would be preserved in the present belt. This does not appear to be acceptable.

This difficulty led Dewey et al. [1989] to assume that a great part of the crust involved in Himalayas shortening was quite thin. We stated earlier that we cannot accept this solution because there is no evidence for marine sediments older than middle Eocene. However, another possibility is that only the upper part of the crust has been conserved within the mountain belt. Butler [1986] has indeed argued that the crust involved in the structure of the mountain belt is mostly upper crust. The palinspastic reconstruction of Coward et al. [1987] clearly shows the small thickness of preserved crust. Coward et al. [1987] assume that lower crust is somehow decoupled and transferred further north. In the same way, Zhao and Morgan [1985] assumed that the ductile lower crust is injected at depth below Tibet. Alternatively, part of the lower crust might be transferred to the mantle by eclogitization.

In any case, if only the brittle upper $20 \mathrm{~km}$ of crust are still preserved within the Himalayas [Le Pichon et al., 1988], the amount of shortening is increased to about $2.5 \times 10^{6}$ to $2.75 \times 10^{6} \mathrm{~km}^{2}$. The estimates of Greater India made earlier require between $2.0 \times 10^{6}$ and $2.5 \times 10^{6} \mathrm{~km}^{2}$ of shortening. These figures correspond to an average thickness of preserved crust between 20 and $25 \mathrm{~km}$ out of the original $38.5 \mathrm{~km}$. The corresponding average velocity of shortening along the Himalayas since 45 $\mathrm{Ma}$ is 15 to $18.5 \mathrm{~mm} \mathrm{yr}^{-1}$.

We conclude that, as an average, only the upper 20 to $25 \mathrm{~km}$ of Indian crust involved in the shortening within the Himalayas have been preserved in the mountain belt and that the lower portion of crust has been either transferred to the mantle or fed into Tibetan crust [Butler, 1986; Le Pichon et al., 1988]. The amount of lower crust involved is very large, about $5 \times 10^{7} \mathrm{~km}^{3}$. It is unlikely that such a large amount would have entirely disappeared below the relatively narrow belt. This solution would imply that the hidden roots of the Himalayas extend to 140 km depth. If the missing lower crust has been entirely transferred below Tibet [Zhao and Morgan, 1985], then about half of the topography of Tibet would be due to this process and half would be due to local shortening. In any case, it is difficult to escape the conclusion that the amount of surface loss in the Himalayas since $45 \mathrm{Ma}$ is $2 \times 10^{6}$ to $2.5 \times 10^{6}$ $\mathrm{km}^{2}$. This amount implies an average linear shortening of 600 to $850 \mathrm{~km}$, in fair agreement with the post-Oligocene average $18 \pm 7 \mathrm{~mm} \mathrm{yr}^{-1}$ rate of shortening obtained by Molnar [1987] and with the seismic rate of underthrusting of $18 \mathrm{~mm} \mathrm{yr}^{-1}$ (with a large uncertainty) obtained by Molnar and Deng [1984].

\section{CONCLUSIONS}

Because the collision of Tibet with India is constrained by the reorganization of the kinematics of the Indian Ocean and by the geology of Himalayas and Tibet to have been completed at the end of middle Eocene, 45 m.y. ago, the total amount of continental surface lost between India and Eurasia can be estimated fairly precisely. Taking into account some oceanic space which probably existed $45 \mathrm{~m}$.y. ago west of the Chaman fault (northwest of India), the total surface loss has to be less than $68 \times 10^{5}$ but more than $57 \times 10^{5} \mathrm{~km}^{2}$ and probably lies between $57 \times 10^{5}$ and $62 \times 10^{5} \mathrm{~km}^{2}$. Most of this, $45 \times 10^{5}$ to $50 \times 10^{5} \mathrm{~km}^{2}$, occurred between the two syntaxes of the Himalayas; the balance was absorbed northwest of India west of the Chaman fault.

The total linear shortening increases from 1850 to $2600 \mathrm{~km}$ from the western to the eastern syntaxis. The rate of surface loss through the Himalayas was quite constant at $1.1 \times 10^{5} \mathrm{~km}^{2}$ m.y..$^{-1}$ during these 45 m.y. in spite of an abrupt $20^{\circ}$ clockwise reorientation of India's path $7 \mathrm{~m}$.y. ago which eliminated the previous dextral component of motion.

To achieve full collision $45 \mathrm{~m}$.y. ago along the Himalayas, it is necessary to assume between $35 \mathrm{x}$ $10^{5}$ and $42 \times 10^{5} \mathrm{~km}^{2}$ of Asian surface loss and between $20 \times 10^{5}$ and $26 \times 10^{5} \mathrm{~km}^{2}$ of Greater India surface loss. The amount of Asian surface loss corresponds to 1250 to $1900 \mathrm{~km}$ of longitudinal shortening between southern Tibet and Asia at the longitude of Lhasa. The ratio of Greater India surface loss to total surface loss varies between 30 and $45 \%$ for the two extreme solutions. Consequently, both Greater India shortening and Asian shortening are significant, the second one being, however, larger than the first one.

The distribution of crustal thickness in Asia, based on seismological measurements in India, southeastern China, and Tibet appears to have a simple linear relationship with altitude. Each kilometer increase in altitude corresponds to a $7 \mathrm{~km}$ increase in crustal thickness. The zero elevation crustal thickness is about $35 \mathrm{~km}$. Using this simple relationship, we convert volumes of topography into surface loss assuming that crust is globally conserved during shortening. We estimate total area loss. We also estimate equivalent linear shortening along N-S profiles (assuming plane strain shortening along the profile) to examine the E-W distribution of shortening. The estimates are corrected for preexisting topography and erosion.

The amount of area loss corresponding to the topography is between $33 \times 10^{5}$ and $52 \times 10^{5} \mathrm{~km}^{2}$ with a most probable value of $39 \times 10^{5} \mathrm{~km}^{2}$ to be compared to the $57 \times 10^{5}$ to $62 \times 10^{5} \mathrm{~km}^{2}$ of expected continental surface loss. The high value of $52 \times 10^{5} \mathrm{~km}^{2}$ is highiy unlikely as it assumes everywhere no preexisting topography ( $0 \mathrm{~m}$ altitude) $45 \mathrm{~m}$.y. ago. We conclude that there is a deficit of 18 $x 10^{5}$ to $30 \times 10^{5} \mathrm{~km}^{2}$ of shortening which must be 
explained by lateral extrusion of crust and (or) by loss of lower crust into the mantle. We have excluded the alternative solution of anomalously thin Indian crust proposed by Dewey et al. [1989] because it would imply a significant depth of water during upper Eocene and lower Oligocene for which there is no evidence.

An important additional conclusion is that the deficit is distributed rather uniformly west of $95^{\circ} \mathrm{E}$ (the eastern syntaxis). Everything happens as if 600 to $950 \mathrm{~km}$ of linear shortening (depending on the solution chosen) had been transferred elsewhere. Part of this transfer can indeed be found in the excess topography between $95^{\circ}$ and $105^{\circ} \mathrm{E}$, but this excess topography cannot account for more than one third to one half of the deficit.

A budget of the volume of crust in the Himalayas indicates that the present crust of the Himalayas plus the eroded sediments cannot account for more than $10^{6} \mathrm{~km}^{2}$ of shortening of normal thickness crust or about $350 \mathrm{~km}$ of linear shortening as previously concluded by Lyon-Caen and Molnar [1983]. Butler [1986] has proposed that lower crust is not generally found in the belt. If this is correct, then the Himalayas can account for the $2 \times 10^{6} \mathrm{~km}^{2}$ (or more) of shortening proposed in this paper, in agreement with the post-Oligocene average rate of shortening [Lyon-Caen and Molnar, 1985; Molnar, 1987].

This conclusion could be taken as evidence that crust has not been conserved and that large amounts of crust have disappeared in the mantle [Le Pichon et al., 1988]. We prefer the hypothesis proposed by Zhao and Morgan [1985] that at least part of the lower crust missing has been transferred north of the Himalayas below Tibet and contributes to its general elevation. If all of the missing Himalayan lower crust has been transferred below Tibet, half of the elevation of Tibet would be due to local shortening and half to northward migration of Indian lower crust. That large scale migration of lower crust occurs is indicated by the relative uniformity of the height of the Tibetan plateau as pointed out by Zhao and Morgan [1985] and Bird [1991] among others.

In any case, we believe that we have established that one third to one half of the continental surface loss due to collision between India and Asia has not resulted in crustal thickening and the associated topography and must have been accounted by an unknown combination of lateral extrusion and loss of crust in the mantle. If crust is conserved, lateral extrusion accounts for a maximum of one third to one half of the total amount of shortening between India and Asia since $45 \mathrm{Ma}$. This conclusion would be compatible with the proposals of Tapponnier and his coworkers [e.g., Tapponnier et al., 1986]. Alternatively, if a significant part of the lower crust has been eclogitized, the amount of extrusion could be reduced to as little as $10 \%$, the minimum amount compatible with the eastward transfer of Tibetan crust. This conclusion leaves open the possibility that the partitioning between extrusion, shortening, and loss of lower crust into the mantle has significantly changed during the $45 \mathrm{~m}$.y. history of the collision. For example, the Indonesian southward facing subduction zone was adjacent to the Indian indenter during the early collision, whereas they are now separated by more than $2000 \mathrm{~km}$. In addition, Australia has been colliding with this subduction zone since upper Miocene. Clearly, lateral extrusion with southward migration of the Indian subduction zone must have been much easier during upper Eocene and Oligocene than since upper Miocene.

Acknowledgments. This paper had its origin in lectures given by the first author in College de France. We thank Nicolas Chamot-Rooke and JeanMichel Gaulier for help in processing data and for discussions as well as Claude Rangin, Philippe Huchon, and Pierre Henry. We thank John Dewey, Peter Bird, and Kevin Burke for their reviews. John Dewey and Peter Bird insisted on the importance of eclogitization in the quantitative budget.

\section{REFERENCES}

Achache, J., V. Courtillot, and Y. Xiu, Paleogeographic and tectonic evolution of southern Tibet since midle Cretaceous time: New paleomagnetic data and synthesis,J. Geophys. Res., 89, 10311$10339,1984$.

Armijo, R., P. Tapponnier, J.L. Mercier, and H. T. Lin, Quaternary extension in Southem Tibet: Field observations and tectonic implications, J. Geophys. Res., 91, 13803-13872, 1986.

Armijo, R., P. Tapponnier, and H. Tonglin, Late Cenozoic right-lateral strike-slip faulting in Southern Tibet, J. Geophys. Res., 94, 2787-2838, 1989.

Besse, J., and V. Courtillot, Paleogeographic maps of the continents bordering the Indian Ocean since the Early Jurassic, J. Geophys. Res., 93, 1179111808, 1988.

Besse, J., and V. Courtillot, Revised and synthetic apparent polar wonder paths of the African, Eurasian, North American and Indian plates, and time polar wonder since
$200 \mathrm{Ma}, J$. Geophys. Res., 96, 4029. 4050, 1991.

Bird, P., Initiation of intracontinental subduction in the Himalaya, $J$. Geophys. Res., 83, 4975-4987, 1978.

Bird, P., Lateral extension of lower crust from under high topography in the isostatic limit, J. Geophys. Res., 96, 10275-10286, 1991.

Butler, R.W.H., Thrust tectonics, deep structure and crustal subductions in the Alps and Himalaya, J. G. Soc. London, 143, 857-873, 1986.

Chang, C., et al., Preliminary conclusions of the Royal Society and Academia Sinica 1985 geotraverse of Tibet, Nature, 323, 501-507, 1986.

Chen, Y., J.P. Cogné, L. Bourjot, P. Tapponnier, V. Courtillot, and $\mathbf{X}$. Zhu, Cretaceous paleomagnetic results from Westem Tibet and tectonic implications (abstract), Eos Trans. $A G U, 72,103$, 1991.

Copeland, P., and T. M. Harrison, Episodic rapid uplift in the Himalaya revealed by the $40 \mathrm{Ar} / 39 \mathrm{Ar}$ analysis of the detrital $\mathrm{K}$ feldspar and muscovite, Bengal fan. Geology, 18, 354-357, 1990.

Coward, M.P., R.W.H. Butler, M. A. Khan, and J. Kimpe, The tectonic history of Kohistan and its implications for Himalayan structure, J. G. Soc. London, 144, 377-391, 1987.

Curray, J.R., Possible greenschist metamorphism at the base of a $22-\mathrm{km}$ sedimentary section, Bay of Bengal, Geology, 19, 1097-1100, 1991

De Mets, C., R.G. Gordon, D.F. Argus, and S. Stein, Current plate motions, Geophys. J. Int., 101, 425-478, 1990.

Dewey, J.F., R.M. Schackleton, C. Chengfa, and $S$. Yiyin, The tectonic evolution of the Tibetan plateau, Philos. Trans. R. Soc. London Ser. A, 327, 379413, 1988.

Dewey, J.F., S. Cande and W.C. Pitmam, Tectonic evolution of the India-Eurasia 
collision zone, Eclogae Geol. Helv., 82, 717-734, 1989.

England, P., and G. Houseman, Finite strain calculations of continental deformation,.2, Comparison with the India-Asia collisions zone, $J$. Geophys. Res., 91, 3664-3676, 1986.

Haq, B.V., J. Hardenbol, and P.R. Vail, Chronology of fluctuating sea levels since the Triassic, Science, 235, 1156-1167, 1987.

Harland, W.B., A.V. Cox, P.G. Llewellyn, C.A.G. Pickton, A.G. Smith, and R. Walters, A Geologic Time Scale, 131 pp. Cambridge University Press, New York, 1982.

Him. A., et al., Lhasa block and bordering sutures: a continuation of a $500 \mathrm{Km}$ Moho traverse through Tibet, Nature, 307, 25 27, 1984.

Kent, D.V, and F.M. Gradstein, A Jurassic to recent chronology, in The Geology of North America, vol. M, The Western Atlentic Region, edited by P.R. Vogt and B.E. Tucholke, pp. 45-50, Geological Society of America, Boulder, Colo., 1986.

Kie, T. T., Geodynamic and tectonic evolution of the Panxi Rift, Tectonophysics, 133, 287-304, 1987.

Klootwijk, C.T., P.J. Conaghan, and C. Mc

A. Powell, The Himalayan arc, large scale continental subduction, oroclinal bending and back arc-spreading, Earth Planet. Sci. Lett., 75, 167-183, 1985.

Le Pichon, X., F. Bergerat, and M.J. Roulet, Plate kinematics and tectonics leading to the Alpine belt formation: a new analysis, Spec. Pap. Geol. Soc. Am., 218, 111-131. 1988.

Leg 116 Shipboard Scientific Party, Collision in the Indian Ocean, Nature. 330, 519-521, 1987.

Lyon-Caen, H., and P. Molnar, Constraints on the structure of the Himalaya from an analysis of gravity anomalies and flexural model of the lithosphere, $J$. Geophys. Res., 88, 8171-8191, 1983.

Lyon-Caen, H., and P. Molnar, Gravity anomalies, flexure of the Indian plate, and the structure, support and evolution of the Himalaya and Ganga Basin, Tectonics, 4 , 513-538, 1985.

$\mathrm{Ma}, \mathrm{X}$., and D. Wu, Cenozoic extensional tectonics in China, Tectonophysics, 133, 243-255, 1987.

Ma, X., G. Liu, and J. Su, The structure and dynamics of the continental lithosphere in north-northwest China, $A n n$. Geophys., 2, 611-620, 1984.

Mercier, J.L., R. Armijo, P. Tapponnier, E. Carey-Gailhardis, and T.L. Han, Change from Late Tertiary compression to Quaternary extension in Southern Tibet during the India-Asia collision, Tectonics, 6, 275-304, 1987.

Molnar, P., Inversion of profiles of uplift rates for the geometry of dip-slip faults at depth, with examples from the Alps and the Himalaya, Ann. Geophys., 5, 663670, 1987.

Molnar, P., and Q. Deng, Faulting associated with large earthquakes and the average rate of deformation in Central and Eastern Asia, J. Geophys. Res., 89, 62036227, 1984.

Molnar, P. and H. Lyon-Caen, Some simple aspects of the support, structure and evolution of mountain belts, Spec. Pap. Geol. Soc. Am., 218, 179-207, 1988.

Molnar, P., and P. Tapponnier, Cenozoic Tectonics of Asia: effects of a continental collision, Science, 189, 419-426, 1975.

Patriat, P., Reconstitution de l'évolution du système de dorsales de l'Océan Indien par les méthodes de la cinématique des plaques, Thèse d'état, 308 pp., Univ. Paris 7, Paris, 1983.

Patriat, P., and J. Achache, Indian-Asia collision chronology has implications for crustal shortening and driving mechanisms of plates, Nature, $311,615-$ 621, 1984.

Powell, C.M.A., S.A. Roots, and J.J. Veevers, Pre-breakup and continental extension in East Gondwanaland and the early opening of the Eastem Indian Ocean, Tectonophysics, 155, 261-283, 1988.

Royer, J.R., and T. Chang, Evidence for relative motions between the Indian and Australian Plates during the last $20 \mathrm{~m}$.y. from plate tectonic reconstructions: Implications for the deformation of the Indian-Australian plate, J. Geophys. Res., 96, 11779-11802, 1991.

Royer, J.Y., and D.T. Sandwell, Evolution of the Eastem Indian Ocean since the Late Cretaceous: Constraints from Geosat altimetry, J. Geophys. Res., 94, 13755 13782, 1989.

Searle, M.P., et al., The closing of Tethys and the tectonics of the Himalaya Geol. Soc. Am. Bull., 98, 678-701, 1987.

Sharma, S.R., A. Sundar, V.K. Rao, and D.V. Ramana, Surface heat flow and $P_{n}$ velocity distribution in Peninsular India, $J$. Geodyn., 13, 67-76, 1991.

Tapponnier, P., and P. Molnar, Slip-line field theory and large scale continental tectonics, Nature, 264, 319-324, 1976.

Tapponnier, P., and P. Molnar, Active faulting and tectonics in China, $J$. Geophys. Res., 82, 2905-2930, 1977.

Tapponnier, P., and P. Molnar, Active faulting and Cenozoic tectonics of the Tien Shan, Mongolia and Baikal regions, J. Geophys. Res., 84, 3425-3459, 1979.

Tapponnier, P., G. Peltzer and R. Armijo, On the mechanisms of the collision between India and Asia, Geol. Soc. Spec. Publ. London, 19, 115-157, 1986.

Taymaz, T., J. Jackson, and D. McKenzie, Active tectonics of the north and central Aegean Sea, Geophys. J. Int., 106, 433490, 1991.

Treloar, P.J., and M.P. Coward, Indian Plate motion and shape: constraints on the geometry of the Himalayan orogen, Tectonophysics, 191, 189-198, 1991.

Veevers, J.J., and C. Powell, Sedimentary wedge progradation from transform faulted continental rim : Southem Exmouth Plateau, Westem Australia, AAPG Bull, 63. 2088-2096, 1979.

Zhao, W.L., and W.J. Morgan, Uplift of Tibetan Plateau, Tectonics, 4, 359-369, 1985.

Zhao, L.S., D.V. Helmberger, and D.G. Harkrider, Shear velocity structure of the crust and upper mantle beneath the Tibetan plateau and southeastern China, Geophys. J. Int., 105, 713-730, 1991.

Zorin, Y.A., M.R. Novoselova, E.K. Turutanov, and V.M. Kozhevaikov, Structure of the lithosphere of the Mongolian Siberian mountainous province, J. Geodyn., II, 327-342, 1990.

Zonenshain, L.P. and L.A. Savostin, Geodynamics of the Baikal Rift zone and plate tectonics of Asia, Tectonophysics, $76,145,1981$.

M. Foumier, L. Jolivet, and X. Le Pichon, Laboratoire de Géologie, Département Terre-Atmosphère-Océan, Ecole Normale Supérieure, 24, rue Lhomond, 75231 Paris cedex 05, France.

(Received November 27, 1991; revised May 15, 1992;

accepted June 26, 1992.) 